\title{
Ethnic Politics and Conflicts in Nigeria: Theoretical Perspective
}

\author{
Joseph C. Ebegbulem \\ University of Calabar, Nigeria
}

\section{Introduction}

In Africa, colonial administrations and imperial occupations carved up boundaries that divided territories inhabited by indigenous societies and brought together a diversity of ethnic communities within unitary administrative structures. In Nigeria, between 1914 and 1915, British colonial administrators created the three regional territories that explain "ethno-genesis" and later "ethno-tensions": The Northern region was occupied by Hausa/Fulani, the Eastern region inhabited by the Igbos and the Western region by the Yorubas. Within this divisive colonial structure, ethnic tensions emerged between these unequally developed groups primarily in the 1950s. The colonial tripartite division of Nigeria prevented a Nigerian nationalistic movement, manipulating geographical boundaries to reinforce separation between ethnic groups and transforming ethnicity into an identity by which to gain political power; this structure along with other administrative decisions emphasized ethnic nationalism and regional politics, resulting from significant uneven development within each region. The colonial division of Nigeria that reinforced ethnic groups, the rise of ethno-political consciousness, and the development of ethnic/regional political parties demonstrated that the British administration intentionally prevented the rise and success of Nigerian nationalism, instead promoting ethnic nationalism as a means to gain political power.

As ethnic consciousness motivated the majority ethnic groups to develop regional political parties which stimulated inter-ethnic tensions, ethnic politics inevitably became the main deterrent to Nigerian nationalism. In each region, a party dominated by members of the majority ethnic group obtained office and provided services and patronage for the group (Cooper, 2002). The Hausa/Fulani led the Northern Peoples Congress (NPC) and the Northern Elements Progressive Union (NEPU); In the East, the Igbos formed the National Council for Nigerian Citizens (NCNC); the Yorubas formed the Action Group (AG), a regional political party 
dedicated to strengthening ethnic politics in the west (Coleman, 1960).

The politics of ethnic and regional security play a key role in Nigeria's political and economic development as well as its role in Africa and the world in general. It is the major source of growing political crisis in Nigeria. It undermines the selection of responsible and responsive national leadership by politicizing ethnicity. National leaders are recruited on the basis of ethnicity and region, rather than their ability, experience and vision, hence, Nigeria's political and economic performance falls below par in comparison with other countries of comparable size and resources. The primacy of ethnicity has resulted in periodic outbreaks of violence between different ethnic groups in Nigeria. Census enumeration for economic planning and electoral representation has fallen victim to the same ethnic politics as different ethnic groups and regions claim bloated population numbers in order to secure more government funding and representation. It is also often the factor that determines the location of industries and development projects rather than feasibility studies or viability of the location.

Politicized ethnicity has been detrimental to national unity and socio-economic wellbeing. It is important to note that most of these ethnic conflicts were caused by colonialism, which compounded inter-ethnic conflict by capitalizing on the isolation of ethnic groups. The "divide-and-rule" method was used by the British to pitch ethnic groups against each other, thus keeping the people from rising against the colonizers. Distribution of economic resources was often skewed to favour a particular group, pushing marginalized groups to use their ethnicity to mobilize for equality. These are the seeds of conflict.

\section{Ethnicity: Conceptual Approach}

A liberal scholar, Mair who is an anthropologist sees an ethnic group as a people sharing the same historical experience, having the same culture, speaking the same language and sharing the belief about the future together (Mair, 1962). Other liberal theorists (Zolberg, 1968), Oyovbaire (1974), Mitchell (1974), Young (1976), Stavenhagen (1997) see ethnicity as an inevitable consequence of modernization, economic development and political development, especially in Africa. The liberal theorists believe that an ethnic group has as its members, people who share a conviction that they have common interests and fate, and they tend to propound a cultural symbolism expressing their cohesiveness. Ethnic groups differ from other groups in their composition because they include persons from every stage of life and social class. It is suggested that the insignia of ethnicity is inescapable. Kasfir (1976) suggests four ways of recognizing ethnic groups. These 
are (i) culture; (ii) language; (iii) traditional political organization; and (iv) territoriality. Succinctly, members of an ethnic group must share a common culture, language and custom and occupy the same territory.

According to Okwudiba Nnoli (2007) "In reality, ethnicity is a very complex phenomenon.... It is always closely associated with political, economic, social, religious and other social views and interactions. Hence ethnicity finds expression in political domination, economic exploitation, psychological oppression and class manipulation." Perhaps the commonest explanation of what an ethnic group means is that which says that it comprises people with a common ancestry. In other words, this refers to people who can trace their pedigrees to one ancestor. Apparently, most definitions and explanations on the term, by social scientists, seem to draw from this perspective. Max Weber (1968) for instance, described the ethnic group as "those human groups that entertain a subjective belief in their common descent."

The main elements of ethnicity according to Nnoli (1978) include "exclusiveness manifested in inter-group competition, conflict in relation to stiff competition, and the consciousness of being one in relation to others."

In addition to these, Mair (1993) identify three main characteristics of ethnicity. "One, it is a culturally specific practice and unique set of symbols and beliefs, especially the way in which an ascribed identity is given contemporary construction through socialization and mobilization in cultural and political movements. Two, it is a belief in common origin involving sometimes, the existence or imagination of a common past. Third and finally, it involves a sense of belonging to a group defined in opposition to others."

A critical examination of these three elements on which ethnic identity rests shows an attempt to bridge the gap in literature between those who take ethnicity as a primordial inheritance and those who see it as something that is historically or socially constructed. Indeed, there is an increasing tendency to discard the earliest approaches to the conceptualization of ethnicity. These include approaches hat emphasize ethnicity as primordial (Geertz, 1963) and those that present ethnicity as a hang-over of the past which modernization - access to the media, western education and urbanization are expected to whittle down in the course of time.

\section{A Panoramic Overview of Ethnic Politics in Nigeria Since Independence}

Nigeria as a country is a conglomeration or an aggregation of several nationalities which makes the country a pluralistic and multi-faceted society. The diversity of 
languages, customs and traditions gives the country a rich cultural diversity. Nigeria is said to be a British creation by uniting the various nationalities into a single country today known as The Federal Republic of Nigeria. This is the amalgamation of 1914 by Lord Frederick Lugard. The amalgamation brought together the protectorate of Northern Nigeria, the colony of Lagos and Protectorate of Southern Nigeria into one country. This was done to serve the interest of Britain without the consent of the various ethnic nationalities. This act marked the beginning of ethnic struggle for power in Nigeria.

Since Nigeria achieved political independence in 1960, there has been struggle among the various ethnic nationalities in the country over control of political power and natural resources which led to the civil war from 1967 - 1970. Since independence, Nigeria's democracy has been characterized by ethnic-based politics. In the First Republic, the incidences of ethnic and prebendal politics were evident in the power tussle between the three dominant parties, notably Action Group (AG) led by Chief Obafemi Awolowo, with its base among the Yorubas of the Southwest; the National Council of Nigerian Citizens (NCNC) led by Dr. Nnamdi Azikiwe with its base among the Igbos of the Southeast; the Northern Peoples Congress (NPC) led by Sir Ahmadu Bello with its base among the HausaFulani in the Northern part of the country. This tripod balance reverberated again in the Second Republic with the Unity Party of Nigeria (UPN) under the leadership of Chief Obafemi Awolowo holding sway in the Southwest. The bulk of its loyalists were former disciples of Chief Obafemi Awolowo. The party was dominated by the Yorubas. The Nigeria People's Party (NPP), led by Dr. Nnamdi Azikiwe, like the NCNC, held sway in the Igbo states of Southeastern Nigeria while the National Party of Nigeria (NPN) which had a more national outlook, had its major support base in the North and reflected the legacies of the defunct NPC. It must be noted that these ethnic based political parties were more of a reincarnation of the ethnic politics of the First Republic.

The military regime of General Ibrahim Babangida attempted to eradicate this tripod divide in party politics in Nigeria by establishing the Social Democracy Party (SDP) and the National Republican Convention (NRC) as the two major political parties in the botched Third Republic. This approach almost succeeded to end ethnic undertone to party politics in Nigeria but for the unfortunate annulment of the Presidential Election of June 12, 1993 widely believed to have been won by Bashorun M.K.O. Abiola from the Yoruba extraction of the Southwest. It must be noted that the annulment generated intense ethic, populist and regional antipathy particularly in the Southwestern part of the country and further reinforced the contention that there existed a northern oligarchy ready at all times to resist any power shift away from the North. According to Burkhalter (1993), the tragedy of 
the crisis then is that Nigerians all over the country who in the election of 1993 seemed to have overcome a legacy of ethnic conflict and regional barrier to vote Chief Abiola have been forced once again to narrow their sight and put ethnic identity first, rather than their citizenship as Nigerians.

In the current Fourth Republic, the incidence of ethnic oriented politics found its manifestation in the activities of Action Congress of Nigeria (ACN) dominated mostly by the Yorubas of the Southwest; All Progressive Grand Alliance (APGA) which has a predominantly Igbo membership in the Southeast; the Congress for Positive Change (CPC) dominated by the Hausa-Fulani of Northern Nigeria. So far, it can be said with a great measure of certainty that it is the ruling People's Democratic Party (PDP), that has a huge membership across ethnic lines and has so far dominated the thrust of national and local politics throughout the country in this Fourth Republic.

\section{The Injustice Of Ethnic Politics In Nigeria}

As discussed above, amongst the federating units in Nigeria and the over 250 ethnic groups, the Igbo, Yoruba and Hausa ethnic groups have always dominated national politics. Perhaps, this may be as a result of their greater numbers in population, likewise their somewhat active involvement and participation in successive governments since Nigeria achieved colonial independence in 1960. Such domineering presence and control of what Nigerians choose to call the "national cake" has always irked the other ethnic groups who are in the minority. These minority groups feel left out in the scheme of things in Nigeria, a situation that has now bred distrust, fear and sense of hopelessness; this invariably affects their sense of patriotism, likewise their national identity and psyche. Within the smaller ethnic groups appear to be a rising feeling of sub-nationalism, of a need and desire for the groups to take their own fate into their hands. They question the concept of nationhood in a Nigerian system with less than caring attitude and posture towards issues that affect them.

The Niger Delta people located in the South-South geo-political region of Nigeria epitomize this struggle for political and economic emancipation. Years of exploitation of the natural resources which abound plentifully in their region by oil exploration companies has culminated in a situation of despair for the people. Successive Niger Delta leaders and opinion leaders have tried in the past to draw the attention of the world to the plight of the region to no avail. Years of failed promises by successive Nigerian governments and oil companies operating in the region has finally snapped the patience of the people. The Ijaws of this region have 
now risen. The struggle for an independent Ijaw State, or an Ijaw State to be reckoned with, within a united Nigeria entered another phase; that of armed struggle and kidnappings until they were pacified by the government's amnesty programme.

According to Ndoma Egba (2000) the urgent and immediate concern of the minority ethnic group from the Niger Delta region of Nigeria where the greater part of the country's wealth is produced is their desire to be considered by the rest of the country as equal stakeholders in the Nigerian project. Their expectation is a fair and just recompense in their contribution to the national economy and the pain of their environmental degradation and social dislocation consequent upon the exploitation of the natural resources from their area.

It is the failure of the Nigerian state to meet the demands of these minority ethnic groups that has always manifested in agitation that often leads to conflicts. The more they believe that the failure to meet these demands is deliberate and unjustified, the more violently the agitation is expressed.

\section{Ethnic Conflict In Nigeria}

\section{A. Colonial Era}

The history of ethnicity and ethnic conflicts in Nigeria is traced back to the colonial transgressions that forced the ethnic groups of the northern and southern provinces to become an entity called Nigeria in 1914. Since the various ethnic groups living in these provinces were not consulted regarding the merger, this British colonial policy was autocratic and undemocratic, and thus led to conflict. It denied the people's basic needs of participation, equality and social wellbeing. An administration that endorses segregation for its people does not have the unity of the country at heart. Rather, the separate governments introduced in the North and the South was designed to strengthen the colonial grip on Nigerian society and weaken the people's potentials for resistance. This era of provincial development, though relatively peaceful, also led to growing ethnocentrism.

The introduction of indirect rule in Nigeria by Lord Frederick Lugard, the chief administrator, was not the appropriate mechanism for managing tribal animosity in the colony. The system not only reinforced ethnic division, "it complicated the task of welding diverse elements into a Nigerian nation" (Coleman 1958 as cited in Okwudibia 1980). This strategy of governance distanced ethnic groups from each other. Lord Lugard gave power to the traditional rulers who corruptly used it in the 
villages to amass wealth, land and establish patronage networks, which, in the long run, encouraged tribalism and nepotism. The segregation of the Nigerian colony was also reinforced by the colonial laws that limited the mobility of Christian southerners to the Muslim North, created a separate settlement for non-indigenous citizens in the North, and even limited the purchase of land outside one's own region (Afigbo, 1989). Prejudice and hatred became rife in the provinces as different ethnic groups started looking at each other suspiciously in all spheres of contact. Unequal and differential treatment of ethnic groups was responsible for the intense competition in Nigerian society. It created disparity in educational achievement and widened the political and economic gaps between Northern and Southern Nigeria.

During this period, there was significant scarcity of all goods, "evident in the economic, social and political areas of life. It affected employment, education, political participation and the provision of social services to the population" (Nnoli 1980). The lack of such basic needs always gave the elites the ability to mobilize groups for intense competition, employing ethnocentrism to achieve their goals. In 1947, a colonial constitution divided Nigeria into three political regions: East, West and North. The North, which was predominantly Hausa-Fulani, was the largest and eventually the most populous region. The Igbos dominated the East and the Yorubas the West. Osaghae, (1991) and Subaru, (1996) observed that with the three major ethnic groups in dominance, the minority groups rebelled and Nigerians started fighting for ethnic dominance as the nation marched towards independence.

\section{B. The Post Colonial Era}

The years between 1952 and 1966 brought changes in the political culture of Nigeria, transforming the three regions into three political entities. Thus, the struggle for independence was reduced to the quest for ethnic dominance. At this time, ethnic and sub-ethnic loyalties threatened the survival of both East and West while the North was divided religiously into Christianity and Islam. It was a period of politicized ethnicity and competition for resources, which worsened the relationship between ethnic groups. There was a high degree of corruption, nepotism and tribalism. The national interest was put aside while politicians used public money to build and maintain patronage networks. Since independence, the situation in Nigeria has been fraught with ethnic politics whereby the elite from different ethnic groups schemed to attract as many federal resources to their regions as possible, neglecting issues that could have united the country. 
The anarchy, competition and insecurity led to the demise of the first republic. Military intervention culminated in the gruesome ethnic war from 1967 to 1970, when the mistreated Igbos of Eastern Nigeria threatened to secede from the federation. The Igbo's grievances were caused by the denial of their basic human needs of equality, citizenship autonomy and freedom. Wherever such basic needs are denied, conflict often follows as aggrieved groups use violent means to fight for their human rights (Burton, 1992).

While the politicians tried to cope with the colonial legacy that lump incompatible ethnic groups together into one country, the military elite staged coups, making mockery of democracy in Africa's most populous and promising country. The corruption, ineptitude and confusion that marked the military era plunged Nigeria into economic problems, poverty and ethno-religious conflicts until the 1990s. In a country, where politics still follows ethnic lines, there is always disagreement about the rules of the game. The military intervened because they viewed the civilian leaders as inept and indecisive. However, the Southerners distrusted the military regime because they felt it was trying to maintain a Hausa-Fulani hegemony in Nigeria. On June 12, 1993, Chief Moshood Abiola, a Yoruba from Southwestern Nigeria, won Nigeria's presidential election, but his presidency was annulled by the military regime controlled by the Northerners. In retaliation, Southern Nigerians began to form militant organizations to protest unfair treatment and demanded for a democratically elected government. During the authoritarian rule of General Sani Abacha, a Muslim from the North, Southerners increasingly feared political marginalization and demanded for an end to the Hausa-Fulani domination of the political arena. This development signified the weakness of the government and their lack of effective mechanism to manage ethnic conflicts in Nigeria.

Adding to the ethno-religious conflict in Nigeria, was the Yorubas' boycott of the 1994 constitution conference arranged by General Abacha's regime. The conference was meant to resolve the national debate over ethnicity. Inspired by the pan-Yoruba cultural and militant groups, the Afenifere and Odua Peoples Congress $(\mathrm{OPC})$, the Southwestern Nigeria threatened secession and intensified violent protest across the country.

Ethnic conflicts in Nigeria continued through the democratic transition. Conflict continued to escalate, as various ethnic groups demanded for a political restructuring. The federal structure has developed deep cracks and there was urgent need to mend it. What is most worrisome is the religious dimension of ethnic competition for power and oil wealth in Nigeria. The multiple ethno-religious conflicts in the northern cities of Kano, Kaduna, Jos and Zamfara spring from the 
introduction of Muslim Sharia courts, and the South's demands for autonomy. There has been serious agitation by the Niger-Delta region for absolute control of the resources derived from that area. This has resulted in the vandalization of oil pipelines and the frequent kidnapping of expatriate oil workers.

\section{The Nigerian Civil War: A Consequence of Ethnic Politics and Tensions in Nigeria}

The Nigerian civil war was the result of ethnic and religious tensions among two major ethnic groups of Nigeria. Like many other African countries, Nigeria was an artificial structure initiated by the British which had neglected to consider religious, linguistic and ethnic differences. Nigeria, which won independence from Britain in 1960, had at that time a population of about 60 million people consisting of about 250 differing ethnic and cultural groups.

The Nigerian civil war which started in 1967 was a political conflict caused by the attempted secession of the Eastern region of Nigeria under the leadership of Lt. Col. Chukwuemeka Odimegwu Ojukwu. According to Udo (1972), there were close to 3,000,000 military casualties and civilian deaths from starvation. Following independence in 1960, three regions were created along ethnic lines. These are the Northern region dominated by the Hausa-Fulani, the Eastern region dominated by the Igbos and the Western region dominated by the Yorubas. The fourth region, the Midwestern region, was created from the western region after Nigeria became a Republic in 1963.

Ethnic tensions increased after a military coup in January, 1966 led by Major Kaduna Chukwuma Nzeogwu. The coup was seen by the Northerners as an attempt by the Igbos to dominate the country. This led to a counter coup led by the Northerners few months later. In the counter coup, Aguiyi Ironsi, an Igbo Major General who was the then Head of State was killed and widespread reprisals were unleashed against the Igbos in the Northern part of the country. Fearing marginalization within the state, on May 30, 1967 the Eastern region dominated by the Igbos declared its independence as the Republic of Biafra.

The Nigerian government launched a "police action" to repossess the secessionist territory as it declared Ojukwu's action as a rebellion and promised to crush it. As observed by Osaghae, "fighting broke out between federal and Biafran forces on July 6, 1967, with Gowon ordering "police action" in a war which he and other top federal military officers believed would not last long." (Osaghae 2002). The war cost Nigeria a great deal in terms of lives, money and its image in the world. It has 
been estimated that about three million people died as a result of the war, most from hunger and disease.

The war ended on January 12, 1970 with the announcement of Lt. Col. Philip Effiong (Ojukwu's Second in Command) of the surrender of Biafra. After the war, "the federal government embarked on a vigorous policy of reintegration and rehabilitation built around the "three Rs" Reconstruction, Rehabilitation, and Reconciliation." Reconstruction, helped by oil money, was swift; however, the old ethnic and religious tensions remained a constant feature of Nigerian politics. Military government continued in power in Nigeria for many years, and people in the oil producing areas claimed they were being denied a fair share of oil revenues.

\section{The Remote and Immediate Causes of the Civil War}

Claims of electoral fraud and maladministration of the civilian government were the ostensible reasons for the military coup on January 15, 1966, led by Major Kaduna Nzeogwu and other Igbo junior army officers, mostly majors and captains. The coup resulted in General Johnson Aguiyi Ironsi, an Igbo and head of the Nigerian army, taking over as head of state, becoming the first military head of state in Nigeria. This coup failed, as Ironsi rallied the military against the plotters. Ironsi then instituted military rule, alleging that the democratic institutions had failed and that, while he was defending them, they clearly needed revision and clean-up before reversion back to democratic rule. The coup, despite its failure, was perceived as having benefitted mostly the Igbos, and Ironsi, himself an Igbo, was thought to have promoted many Igbos in the army at the expense of the Yorubas and Hausa officers (Anwunah 2007).

On July 29, 1966, the Northerners executed a counter-coup. This was led by Lt. Col. Murtala Mohammed. It placed Lt. Col. Yakubu Gowon in power (Momoh 2000). Ethnic tensions due to the coup and counter-coup increased and led, in September 1966, to the large-scale massacre of Igbos living in the North. Osaghae (2002) has argued that it was mostly the genocide against the Igbos in the Northern region and the revenge killings of Eastern officers, including the Head of State General Aguiyi Ironsi, in the July Countercoup, that provided the grounds for Ojukwu's secessionist plans which resulted in the civil war. By the end of September, Ojukwu who had argued that the action of the Northerners against the Igbos had cast serious doubts on whether the people of Nigeria could ever sincerely live together as members of the same country, concluded that the safety of Easterners living outside the region could not longer be guaranteed and asked them to return home. These and other causes led to the Nigerian civil war. 


\section{The Politics of the Civil War}

According to Osaghae (2002) "the war was presented as a genocidal one waged by the Muslims of Northern Nigeria who had declared a jihad to exterminate the Igbos from the face of the earth." This assertion by Osaghae was given credence based on the fact that the Igbos were massacred in the North before and after the commencement of the civil war and "the strategies of economic blockade and starvation were pursued throughout the war." Another scholar who thought in the direction of genocide and starvation as instruments of war used by the government of Nigeria was Simon Ayah. According to him, "the Biafran leaders claimed that Eastern region was pushed out of the federation citing the case of mass massacre (genocide or pogrom) against the indigenes of eastern Nigeria living in the North of Nigeria. As the war progressed, the Biafran leaders claimed also that the federal government had resorted to the use of starvation as an instrument of war (Ayah 1999).

To get the minority ethnic groups on the federal side, the Gowon administration created twelve states out of the four regions. This creation of states was intended to weaken Southern solidarity in relation to the prosecution of the civil war. "In particular, by dividing the Eastern region into three states and creating two Rivers and Southeastern states for minorities in the region, the federal government undercut Eastern solidarity, and this accelerated Biafra's collapse."

The Igbos were disappointed by the attitude of the Western region under the leadership of Chief Obafemi Awolowo. Attempts made by the Igbos to reach out to the Yoruba leaders to find common ground for Yoruba secession after the declaration of the Republic of Biafra did not yield any fruitful outcome. The subsequent alignment of the Yorubas with the federal government during the war was seen as a betrayal by the Igbos. The consequences of this action by the Yorubas could be felt in the inability of the Igbos to fully support the struggle "to actualize the revalidation of June 12, 1993 election which was won by Chief M. K. O. Abiola a prominent Yoruba businessman and politician".

It has been argued that the most serious consequence of the civil war on the Igbos was their marginalization in the post war various governments of Nigeria, especially during the military regimes. The Igbos were under-represented in the armed forces and other key government positions. "This, as many Igbo leaders believed, was why they lagged behind the other ethnic majority groups". After the war, there were just few Igbo senior military officers in the Nigerian army (those who did not play active roles in the secession bid) and some observers of Nigerian politics of Igbo extraction alleged there was an official policy to limit the 
recruitment of the Igbos in the Nigerian army.

The Igbos again felt that they had been deliberately displaced from government positions. When Igbo civil servants left to join similar posts in Biafra, their positions were replaced; and when the war was over the government did not feel that it should sack their replacements, preferring to regard the previous incumbents as having resigned. This, however, has led to a feeling of injustice. Further feelings of injustice were caused by Nigeria, during the war, changing its currency so that Biafran supplies of pre-war Nigerian currency were no longer honoured and then, at the end of the war, offering 20 pounds to Easterners in exchange of their Biafran currency. This was seen as a deliberate policy to hold back the Igbo middle class, leaving them with little or no wealth to expand their business interests. The Nigerian civil war has been viewed and analyzed by scholars as a consequence of ethnic politics and tension which has destroyed the unity of the nation.

\section{Theoretical Approaches to Ethnicity and Ethnic Conflict}

Scholars have been trying to develop some theoretical approaches to ethnicity and ethnic conflict for a long time. Some, like Donald Horowitz, Ted Gurr, Donald Rothschild and Eward Azar, agree that the ethnic conflicts experienced today, are deep rooted. These conflicts over race, religion, language and identity have become so complex that they are difficult to resolve or manage. Ethnicity has a strong influence on one's status in a community. Ethnic conflicts are therefore often caused by an attempt to secure power or access to more resources.

Gurr's (1970) relative deprivation theory offers an explanation based on an ethnic group's access to power and economic resources. This is closely related to Horowitz (1985) who wrote that group worth is based on the results of economic and political competitions. According to lake and Rothschild, (1996) ethnic conflicts is a sign of a weak state or a state embroiled in ancient loyalties. In this case states act with bias to favour particular ethnic group or region and behaviours such as preferential treatment fuel ethnic conflicts. Therefore, in critical or difficult political situations, the effectiveness of governance is dependent on its ability to address social issues and human needs.

Recently, scholars have come out with different approaches to conceptualizing ethnicity. Faced with the proliferation of separatist conflicts in North America, the inadequacies underlying modernization theory are being exposed. The notion that modernity would result in smooth transition from community to association, with gradual dissolution of ethnic affiliations, simply did not work. Ethnicity has 
persisted in many parts of the world including Nigeria. This failure simply means that ethnicity will remain and that the stability of many states, especially those in Africa is threatened not be ethnicity per se, but by the failure of national institutions to recognize and accommodate ethnic differences and interests. According to this argument, the lesson for ethnic conflict management is that government should not discriminate against groups or they will create conflict.

The second theory is from the primordial school which stresses the uniqueness and the overriding importance of ethnic identity. From their point of view, ethnicity is a biological and fixed characteristic of individuals and communities (Geertz, 1963).

The third theoretical approach is the instrumentalist approach. In Africa where poverty and deprivation are becoming endemic, mostly as a result of distributive injustice, ethnicity remains an effective means of survival and mobilization. Ethnic groups that form for economic reasons, easily disband after achieving their objectives (Moynihan, 1975). This corresponds with Anderson's (1991) argument that ethnicity is a "construct" rather than a constant.

Another important theory on conflict and conflict management is John Burton's (1979) human needs theory. This theoretical approach to ethnic conflict explains that ethnic groups fight because they are denied not only their biological needs, but also psychological needs that relate to growth and development. These include people's need for identity, recognition, participation and autonomy. This theory provides a plausible explanation of ethnic conflicts in Nigeria, where such needs are not easily met by successive governments.

\section{Conclusion}

The Nigerian state is composed of various ethnicities. The amalgamation of diverse ethnic groups into one nation called Nigeria by the British brought with it several problems. The major challenges which these artificial creations continue to face include how best to resolve the conflicts which they have engendered.

Nigeria has witnessed a lot of ethnic disputes and conflicts over allocation and sharing of resources, power and position.

The colonial administration of Nigeria along ethnic lines promoted ethnic tensions which prevented a Nigerian nationalistic movement but rather encouraged ethnic nationalism and regional politics.

Against the backdrop of ethnic conflicts and ethno-nationalism which characterized the Nigerian state and her politics during pre-independence and post-independence eras, this paper has shown that politicized ethnicity has been detrimental to national 
unity and socio-economic well-being of the Nigerian state. We have been able to deduce from facts available that the existence of ethnicity is not enough to provoke conflicts, but economic underdevelopment, marginalization and the agitation for resource control provoke ethnic conflicts. Colonial administration before independence also encouraged ethnic differences through the policy of divide and rule.

The colonial division of Nigeria which reinforced ethnic groups gave rise to ethnic conflicts from pre-independence era till date.

It is important to note that most of these ethnic conflicts were caused by colonialism. The divide-and-rule method was used to pit ethnic groups against each other thus keeping the people from rising up against the colonizers. Distribution of economic resources was often skewed to favour a particular group, pushing marginalized groups to use their ethnicity to mobilize for equality.

As a result of ethnic and regional tensions resulting from uneven socioeconomic development in the North, East and West, ethnic consciousness influenced the formation of regional political parties and was and still is the main deterrent to Nigerian unity. Ethnic tensions which increased after the military coup of January, 1966 metamorphosed into a bloody civil war which lasted for thirty months with a lot of casualties.

\section{References and notes}

Afigbo, P. (1989) British Colonial Administration in Nigeria. Lagos: Heinemann Anwuna, P. A. (2007) The Nigeria-Biafra War (1967-1970): My Memoirs. Ibadan: Spectrum Books.

Ayah, S. O. (1999) International Organizations. Enugu: Jamoe Enterprises Ayo, D. (2007) "Ethnicity, Political Stability and Economic Development in Africa" in "Conflict Resolution, Identity Crisis and Development in Africa".

Celestine, Bassey and Oshita, Oshita (eds). Abuja: Malthouse Press Limited.

Burkhalter, H. (1993) Ethnic Militia in the Niger Delta. London: Oxford University Press

Burton, G. (1992) Beyond Ethnic Politics. Ibadan: University Press

Coleman, J. S. (1960) Nigeria: Background to Nationalism. Berkley: University of California Press.

Cooper, F. (2002). Africa since 1940: The Past of the Present. Cambridge: Cambridge University Press,

Ebegbulem, J. C. (2010) Government and Politics of the Modern State. Calabar: 
Kings View Publishing House

Glickman, H. (1995) "Issues in the Analysis of Ethnic Conflict and Democratization Process in Africa Today" in "Ethnic Conflict and Democratization in Africa". Harvey Glickman (ed) Atlanta: African Studies Association Press.

Mair, S. (1962) Colonial Administration and Africa's Independence. Oxford: Oxford University Press

Mitchell, B. (1987) Ethnic Nationalism in Africa. London: Zed Press

Mnoma, V. (1995) "Ethnic Conflict, Constitutional Engineering and Democracy in Nigeria" in Ethnic Conflict and Democratization in Africa. Harvey Glickman (ed). Atlanta: African Studies Association Press.

Momoh, H. B. (2000) The Nigerian Civil War: History and Reminiscences. Ibadan: San Bookman Publishers

Nnoli, O. (1980) Ethnic Politics in Nigeria. Enugu: Fourth Dimension Publishers

Nnoli, O. (2007) "Theories and Concepts of Ethnicity" in Conflict Resolution, Identity Crisis and Development in Africa" Celestine, Bassey and Oshita, Oshita (eds). Abuja: Malthouse Press Limited.

Obaro, I. (1998) "Professionalize the Army", The Post Express, June 22.

Osaghae, E. (9186) "Do Ethnic Minorities still exist in Nigeria?" Journal of Commonwealth and Comparative Politics, Vol. 24, No. 2.

Osaghae, E. (1998) "Managing Multiple Minority Problems in a Divided Society: The Nigerian Experience" in the Journal of Modern African Studies, Vol. 36, No. 1, Cambridge: Cambridge University Press

Osaghae, E. (2002) Nigeria since Independence: Crippled Giant. Ibadan: John Archers Publishers Limited.

Otite, O. (1990) Ethnic Pluralism and Ethnicity in Africa. Ibadan: Shaneson Limited

Rothschild, D. (1996) "Ethnicity in Sub-Saharan Africa" in International Affairs, Vol. 72 , No. 3

Stavenhagen (1997) Ethnic Consciousness in Developing Africa. Ibadan: Spectrum Books

Welsh, D. (1996) "Ethnicity in Sub-Saharan Africa" in International Affairs, Vol. 72 , No. 3

Young, A. N. (1976) The Struggle for Secession, 1966 - 1970; a personal account of the Nigerian Civil War. London: F. Class 


\section{SUMMARY}

\section{Ethnic Politics and Conflicts in Nigeria: Theoretical Perspective \\ Joseph C. Ebegbulem \\ University of Calabar, Nigeria}

According to Okwudiba Nnoli (2007) "Ethnicity is a social phenomenon associated with contact among ethnic groups that exist within the same political system. it is characterized by cultural prejudice and social discrimination."

Nigeria is confronted with problems which have resulted in the dramatic upsurge in ethnic conflicts which is a bye-product of ethnic nationalism and political demands based on ethnicity. From the colonial period to the return to civil politics since 1999 Nigeria has witnessed the resurgence of political demands along ethnic lines. The liberalization of the polity and the expansion of the political space appear to have provided additional fillip to these ethnic demands. Coming after decades of colonization by the British, military rule and military dictatorship, including the centralization of power and resources that accompanied it, groups and communities that hitherto felt excluded and marginalized are seeking to be accommodated.

Ethnic politics has always been the major source of growing political tension in Nigeria which has resulted in periodic outbreaks of violence between different ethnic groups in the country. This scenario has been detrimental to national unity and socioeconomic development of the country.

This paper seeks to examine ethnicity and ethnic conflict in Nigeria from colonial to post-colonial eras, and $\mathrm{x}$-ray the injustice of ethnic politics in Nigeria. It also delves into a panoramic overview of ethnic politics in Nigeria since independence after a conceptual approach as presented by scholars on the concept. The paper also reviews some theoretical approaches to ethnicity and ethnic conflict. 